\title{
Social Representations of Disabled Childcare in the Press: Faial Island (Azores, Portugal). From the Constitutional Monarchy to the First Republic
}

\author{
Sandro Serpa \\ University of the Azores, Faculty of Social and Human Sciences, Department of Sociology; \\ Interdisciplinary Centre of Social Sciences - CICS.UAc/CICS.NOVA.UAc; \\ Interdisciplinary Centre for Childhood and Adolescence - NICA - UAC. \\ Carlos Miguel Ferreira \\ CICS.NOVA, Lisbon; ISCTE University Institute of Lisbon; Interdisciplinary Centre of Social \\ Sciences - CICS.NOVA, Portugal
}

\begin{abstract}
The aim of this article is to understand the symbolic representations of the assistance strategies aimed at disabled children, expressed in two newspapers published on the island of Faial, in the Azores, in the second half of the 19th and early 20th centuries (covering the time horizon between the end of the monarchic period and the implementation of the First Republic). The technique of documentary analysis and a subsequent qualitative thematic content analysis of childcare news collected in two local newspapers was used. The discursive records produced by the press on the assistance strategies value, on the one hand, an axiological dimension and forms of charitable intervention and, on the other hand, aggregate and reconcile the discourses and techniques inherent to charitable and philanthropic models. This mutual assimilation underlies the achievement of the same objective: the moralisation and integration of invalid childhood and, above all, the protection of the existing social order. We conclude that, perhaps contrary to what would be expected, the charitable logic articulated in a concomitant way with the philanthropic logic survived even with the stabilization of the republican period (result of a revolution that deposed the regime of the constitutional monarchy and implemented the republican regime in 1910 in Portugal whose political elites mobilized an official discourse that advocated the separation between the State and Religion, assigning the State the function of social assistance for children and youth). This demonstrates a certain dissociation, as well as a relative autonomy of conceptions about child and youth care between republican political ideology and current social practices at least in this specific context.
\end{abstract}

Keywords: care; neglected childhood; charity; philanthropy; newspaper publications; monarchy; First Republic; Faial; Portugal

\section{1. introduction}

This article aims to understand the symbolic representations of the care strategies aimed at underprivileged children, expressed in two newspapers published on the island of Faial, in the Azores, in Portugal, in the second half of the nineteenth and early twentieth centuries (covering the time limit between the end of the monarchic period and the implementation of the First Republic).

The starting point of this investigation is made up of representations, which reflect the way society thinks about its relations with the objects that affect it. These representations refer to categories of thought through which, in a given society, its reality is elaborated and expressed. These categories are not given a priori and are not universal in consciousness, but appear linked to social phenomena, transforming themselves into social phenomena subject to observation and interpretation (Durkheim, 1993). 
Social representations are cognitive assessments, forms of practical knowledge about social objects that have as their function the organization of behaviors and communication, allowing to understand how individuals think, feel and create reality. The representations are shaped by the discourses produced by science, but also by ideologies and daily communications (Vala, 1993). A representation speaks as much as it shows, communicates as much as it expresses (Moscovici, 1976, 1988). They name and classify, produce images that condense meanings, attribute meaning, shaping the relational and symbolic processes of production and reproduction of social and cultural identities. The representations include systematic and lasting preferences: values, which provide elements that guide behavior (Almeida, 1990). However, behaviour is not determined by the objective characteristics of the moment, but by the representation of that moment. The representations influence the actions and behaviors of individuals, but are not the behavior itself (Abric, 1984, 1994).

According to Moscovici (1988), the representations aim to make familiar what is unknown to us. The author mentions two sociocognitive mechanisms of communication that generate social representations: anchorage and objectification. The first mechanism makes the unknown familiar, bringing it into a sphere of previous social representations, so that we can compare and interpret them. The second mechanism, objectification, makes the unknown familiar by transforming the representations into something concrete and perceptible. Through communication, social representations are again anchored in new social representations. These new social representations are incorporated into those already known, while simultaneously the latter are transformed by the new representations that emerge in this interaction. Gradually, initially strange ideas become known and part of the collective frames of reference of a society. The notion of anchorage expresses the relationship between generating meaning and communication (Moscovici, 1988).

The media disseminate visions on the most varied themes, which are shared in society (Moscovici, 1976; Castro \& Gomes, 2005), symbolically representing the institutional order (Correia, 2001). In this process, the media are involved in the social construction of reality (Correia, 2001; Tuchman, 1993; Traquina, 1993): they guide the audience's attention, influenciam their perceptions of reality (Graber, 2004; Saperas, 1993; Wolf, 1992; Habermas, 1999; Kasperson et al., 1988), definem the social relevance of the themes and what is under discussion in the ePortfolio.

The media participate in the construction of models of interpretation that allow us to organize, evaluate and judge social events. Valence and Rossiau (2009) see the media as potential anchorage contexts for social representations. The anchorage, which allows the incorporation of new elements in the most familiar knowledge categories, reflects the individuals' propensity to start from pre-existing reference points in their reading grid. The authors start from the idea that a representation is established as a possible point of reference and tends to create a set of meanings beyond the initial frames of thought. In fact, the representation no longer strictly corresponds to the object, because the anchorage process may give it the capacity to become a new reference framework for understanding reality (Valence \& Rossiau, 2009).

According to this perspective, the media can be understood as practices of construction of meaning in public spaces, which allow the configuration of shared universes and guide the themes of conversation of social groups according to debates and controversies determined by the specific interests of these groups (Macedo \& Cabecinhas, 2012). 
In this context, the analysis of the material published in newspapers is of central importance for providing clues on how a given subject is considered, appropriate and represented through the most diverse types of publications (such as news, comments and advertisements) (Cordeiro \& Silva, 2009a). These media consequently shape the way in which the publication reflects, to a greater or lesser extent, what may appear to be socially dominant representations, but which may reflect the position of an elite, for example, in situations of scientific appreciation and political regime change. In particular, "the examination of the various ways in which science entered the daily press in European peripheries in the late nineteenth and early twentieth centuries can bring the history of science closer to political history" (Mergoupi-Savaidou, Papanelopoulou, \& Tzokas, 2012, p. 296), and may even function as a means of social and political struggle (Cordeiro \& Silva, 2009a) and, to some extent, as "voice and construction of public opinion" (Cordeiro \& Silva, 2009b, p. 16).

The news can then be perceived as linguistic artifacts that aim to represent certain aspects of reality and that result from a construction process where several elements of individual, social, ideological, cultural, historical and technological nature interact, among others. These elements are disseminated by the journalistic media and generate news with understandable meaning at a given historical moment and in a given socio-cultural environment, although the ultimate attribution of meaning depends on the consumer of the news (Sousa, 2000). However, this process is not unambiguous. As argued by Cordeiro e Silva (2009b), "While it is true that the press can be considered as a kind of portrait of the society in which it operates, it is also, simultaneously, the engine of progress and development" (p. 9). Thus, it should be borne in mind that the perception of the world, as demonstrated by the sociology of knowledge, shows (some) variation, both between individuals and within the same individual over time, as well as the existence of a possible difference between discourse and practice (Keller, 2011).

The visibility given by the press, in news and editorials published in the late nineteenth century and in the first decades of the twentieth century, to the pillar institutions dedicated to assisting poor children is linked to the belief in the possibility of disseminating examples considered to be models, aimed at ensuring the children, at the same time, protection, education and instruction, in contrast to the criticism of institutions or practices considered negative.

Initiatives in the field of invalid childcare - generally with the designation of asylums - are diverse, showing the succession and combination of different perspectives, namely those of a charitable nature associated with Catholicism, those of a philanthropic nature, typical of 19th-century liberalism, and the assumption of solidarity as a central value, in the case of secular republican morality (Pintassilgo, 2009).

The following is the framework that justifies the present research, the methodology mobilized, culminating in the presentation and discussion of the results obtained and consequent conclusions to be drawn as well as the limitations of the study and suggestions for future deepening.

\section{Methods}

This article aims to understand the symbolic representations of the assistance strategies aimed at disabled children, expressed in two newspapers published on the island of Faial, in the Azores, in the second half of the 19th and early 20th centuries (covering the period between the end of the monarchy and the establishment of the First Republic, on 5 October 1910, with effects, for example, on the Vatican's cut off relations with Portugal and the nationalization of Catholic Church property, which was predominant in Portugal). In order to achieve this objective, the technique of 
documentary analysis and a subsequent qualitative thematic content analysis of the news on childcare and the Asylum for Disabled Children of Horta collected in two local newspapers were preferred. The two newspapers analyzed (O Faialense and O Telégrafo) were published in Faial Island, Azores Archipelago, Portugal, located in the middle of the Atlantic. In the period covered by this research (1857-1926) the number of inhabitants of Itha do Faial varied significantly between 22,000 and 26,000 inhabitants (Matos, \& Silva, 2008; Lima, 2005).

This article is based, in part, on the information collected for research on the Asylum of Disabled Children in Horta (AIDH) (2013) as well as on the information contained therein and, in this sense, the following criteria were used in the selection of the news produced by two local newspapers: The local periodicals O Fayalense (weekly, from 01/04/1857 to 20/01/1895) and O Telégrafo (daily, from 16/04/1904 to 21-06-2004) were consulted in the National Library about the commemorations of the Asylum for Disabled Children in Horta, according to the dates available for continued direct consultation. For all these newspapers the consultation was limited to two temporal moments: between December 5 and January 15 (which includes both the anniversary of the inauguration of the Asylum, as a privileged moment in which the organization is selfcelebrated in a celebration of the Anniversary of the Asylum, which takes place on the day of the Innocent Saints for the Catholic Church, and Christmas, which could be a privileged moment of relationship local community-Asylum and between April 15 and July 15 (covering the following moments: the opening of the Asylum-local community and the celebration of Saint Anthony)".

From this selection of articles directly and explicitly related to Asylum, a qualitative thematic analysis was conducted (Cárdenas, 2010; Carvalho, Massarani, \& Seixas, 2015) that is structured based on the following elements: theme, specific subject, depth, orientation (positive, negative or neutral); type of information (announcement, information, opinion/comment), local, national or international reference. The privileged dimensions in the content analysis were the following: Perception of the condition of invalid childhood; Asylum assistance; Assistance strategies: charity, philanthropy.

\section{Childcare Disabled in Portugal}

Poverty, assistance, charity and philanthropy have always been interconnected, and this connection becomes even stronger when linked to childhood (Sanglard \& Gil, 2014).

Assistance was one of the forms of societal intervention on poverty and the poor. Assistance does not aim to equalise individual positions or to suppress the social difference that separates the rich from the poor; assistance is based on the social structure and aims to mitigate certain extreme manifestations of social differentiation, so that the social structure can continue to be based on this differentiation (Simmel, 1998). Assistance therefore plays a regulatory role in the social system, where the state assists poverty, while private assistance assists the poor (Simmel, 1998).

The assistance and the inherent assistance strategies developed by the dominant social groups, initially organised through devotional and/or professional brotherhoods and later by secular or confessional philanthropic institutions, aimed to provide help, help and resolve situations of deprivation. This aid was directed by public and private entities to individuals or groups considered to be needy and deserving of aid, i.e., it distinguished between the deserving and the non-deserving poor on the basis of their attitude towards work. However, the notion of strategy makes reference not to the intentional and planned search for progress with calculated objectives, but to the active disposition of objectively oriented lines that obey regularities and 
form coherent and socially intelligible configurations, even though they do not follow any conscious rule or aim at premeditated objectives placed as such by a strategist (Bourdieu \& Wacquant, 1992).

The concept of assistance is imbricated with the notions of beneficence (or benevolence), charity and philanthropy. The notion of beneficence was used in discursive records of a religious nature with the meaning of an act of goodness, of doing good, generally attributed to God or as a manifestation of charity; it was subsequently appropriated by the liberal discourse, assuming a secular character and the beneficence being valued as a humanist act, generated by philanthropy (Lopes, 2010a; Silva, 2017). The expression charity, as well as the benevolence variant, was used in Portugal, during Liberalism, as a synonym for social assistance, mainly of a public nature, as demonstrated by the designations of the political bodies responsible in this area, the General Council of Charity (1835) and the Directorate General of Health and Public Charity (1899) (Silva, 2017). In the Portuguese official discourse, the term beneficence was replaced by assistance in the First Republic, with public action in this field now being taken over by the Directorate-General for Assistance (1911).

The notions of charity and philanthropy refer to the practice of good in relation to others, in charity for love of God, in philanthropy for love of man (Lopes, 2010a). It was understood by charity the love of God, which was manifested by deeds. Charity was not works, but it was revealed through them, through acts of love directed to God and through what was done to his male children; it was because God was loved that good was done to those whom God loved. Charity established the communion of the divine with the human and, as a consequence, of men among themselves (Lopes, 2010a). In the religious conception of charity, self-giving was an interaction, but self-giving remained, however, a purely individual and not a social fact. It was about the individual salvation of the donor (Simmel, 1998). Charity was distinguished from mercy because this was compassion for one's neighbour, which was not born from love for God, but from identification with the suffering of others. Mercy, one of God's attributes that flowed from his goodness, was also a feeling that men were capable because, in spite of the fall, they were made in the image of God. God does not feel charity, but mercy; he is merciful, not charitable (Lopes, 2010a).

Philanthropy can be understood as the secularization of Christian charity, which began in the 18th century. It was disseminated and defended by the philosophers of enlightened rationalism, the Masonic movements and the proselytes of the French Revolution, and was introduced in Portugal at the end of the 18th century. Doing good and helping those in need is no longer a Christian virtue but a social virtue. Moving away from piety, the idea of social utility underlies it (Duprat, 1996). Generosity was presented as the virtue of the well-born man, who was inclined to donate, to donate widely, hence the strong presence of the great fortunes among the main philanthropists (Sanglard, 2003).

Philanthropy is the contested practice of an elite that claims for itself the competence to solve social problems based on the expertise acquired in other fields (Lambelet, 2017). The philanthropists have produced a descriptive and normative discourse that integrates the properties of interdependence between the dominant and the dominated, on the one hand, and of concessions to the dominated, on the other. Part of the work of the State and the philanthropists is oriented towards the dangerous classes that need to be helped, those that need 
to be brought into the game. It is about assisting the dominated, that is, removing them from the unbearable state of misery in which they find themselves (Bourdieu, 2012).

\begin{abstract}
"philanthropy differs from charity in that it proposes to be detached from any trace of piety and to have underlying it the idea of 'social utility'. Charity, in this sense, reflects fear of God, the realization of one of the ten commandments - helping one's neighbor - and an attitude of resignation in the face of poverty, while philanthropy, a secularized virtue, is a continuous action, reflected and no longer isolated. Another difference we can notice is that in charity, anonymity is an important value, because the gesture is one of self-denial. In order to carry out their works, they resort to the intermediation of the Church (almsgiving) or of the brotherhoods - lay but devotional institutions - which carry out the works of charity: distribution of bread, soup, warm clothes, maintenance of hospitals, asylums, orphanages, among other actions. Philanthropy, on the other hand, in order to put into practice its works of social utility, requires the gathering of people" (Sanglard, 2010, p. 128).
\end{abstract}

Various aspects that differentiate between charity and philanthropy can then be enunciated. One of the distinctive aspects of charity and philanthropy, which have in common the act of giving and are often used as synonyms, is the degree of interest of their practitioners in the poor. Charity, being a religious obligation for Christians, Jews and Muslims, involves the commitment to alleviate the suffering of the poor, orphans and homeless, while philanthropy, of secular origin and emphasizing the love of man rather than of God, is not so involved with those, In the course of the nineteenth century, it was oriented towards humanitarian causes, among which we can highlight the improvement of prison conditions, the abolition of slavery and the death penalty, and the recognition of the rights of workers, women and non-white people (Bremmer, 1996). Philanthropy is scientific, free of individual interaction and structured around rational organizations (foundations) that advocate the secularization of the social question. However, contrary to the demonstration, it is not a prerogative of the crowds, but of the financial and intellectual elites, whose alliance will take on the face of the "reforming nebulae" in Europe and North America (Lambelet, 2017). Another differentiating aspect between charity and philanthropy is the fact that the former is based on piety, i.e., it presupposes the abdication of all the vanity of its author and advocates anonymity, while the latter is marked by a gesture of utility, in which the advertising of the act of giving becomes a relevant strategy for philanthropists (Sanglard \& Gil, 2014). Charity reflects fear of God and an attitude of resignation in the face of poverty, seeking to minimize suffering, philanthropy, a secularized virtue; it is a continuous action, reflected and not isolated (Duprat, 1996).

Charity resorts to the intermediation of the Church (almsgiving) or of the brotherhoods - lay institutions, but of devotion - which carry out the works of charity: distribution of bread, soup, warm clothes, maintenance of hospitals, asylums and orphanages, among other actions. Philanthropy admits a double meaning: in general, it translates works of social action (charitable or humanitarian), whether or not of confessional inspiration; and, specifically, it opposes works of a religious nature, dissociating itself from any spiritual or missionary character (Duprat, 1996). Philanthropy is now understood as a moral, social and patriotic discourse (Duprat, 1993), privileging the moralization of the popular classes (Castel, 2010). However, there was no passage from the administration of assistance by the Church to the laity; there was a collaboration between the various instances involved, lay or confessional, central or municipal, and even personal or professional (Castel, 2010).

This position expresses a relative articulation of the discourses and techniques inherent to these two care models. Charity began to assume the objectives of philanthropy, such as the prevention 
of disorder, and philanthropy did not completely abandon the religious precepts. Mutual assimilation was possible because both had the same objective: the protection of the existing social order. The struggle between charity and philanthropy was, above all, a political dispute for the domination and tutelage of the poor and the public funds allocated to them. With the ideological legitimation of human degeneration, the philanthropic conception began to encourage the emergence of programs aimed at the moralization of dangerous classes, the prevention of "social danger" and the elimination of social disorder. Unvalid childhood is no longer perceived as being in danger, but as being considered dangerous (Paula, 2005).

In invalid childcare, multiple agents and diverse media have mobilized: State, religious groups, philanthropic societies, medical associations and scientific societies.

The assistance system of the constitutional monarchy was based both on the consolidation of the extended network of Misericordie - non-ecclesiastical institutions, with their own financial resources, under the tutelage of the State - and on the existing hospital structure, of royal, noble or corporate initiative, in the houses of the exposed and, although residual, in the brotherhoods and third orders (with assistance action, but reserved to the brothers). The pious and charitable associations became obliged to subsidize the primary education of the parish in which they were installed. Mutual associations, charitable associations, individual improvements and new foundations - night shelters, asylums for children and the elderly, crèches and nursing homes, dispensaries, dispensaries, supervised by the State - filled in the assistance and educational space resulting from the expulsion of religious orders from Portugal (Reis, 2016), which began in the middle of the 18th century, under the reign of José I and governance of Marquês de Pombal, with the expulsion of the Jesuits, and culminated in the extinction of all religious orders in Portuguese territory, proclaimed by the decree of 30 May 1834 (Silveira, 1980).

The repression of begging, the prevention of disease and the rescue of disability and childhood (abandoned children, but also the indigent who could have parents alive) were the main concerns and lines of intervention of liberal governments (Lopes, 2010b). Begging was indigence transformed into misery by deprivation of the basic needs of survival (involuntary begging) or by criminal idleness and vagrancy (voluntary or criminal begging), either by the act of begging (profitable way of life) or by delinquency (Martins, 1998).

Liberalism chose labor as a fundamental societal value, so the disruptive "vice of idleness" and vagrancy would have to be resolutely repressed. The General Council of Charity, created in 1835, had as its main goal to fight begging, privileging the installation of district begging shelters, where all beggars would be collected and would receive help, education or work (Lopes, 2013). The first of these asylums appeared in Lisbon in 1836, collecting those unable to work and destitute of family and the stray and helpless children from two to six years old.

Asylum provided poor children of both sexes, usually between the ages of three and seven to ten, with warm clothing, moral and civic education, and elementary education. The children stayed in the institution during the day, allowing the mothers to carry out their work. Asylum beggars, beggars' homes, invalid childhood homes and, from the 1870s, day care centres (for children under three or four years of age) and night shelters (for the homeless) were characteristically liberal institutions. They relied on private subscriptions, but were strongly driven by governments. The express support of King D. Luís for night shelters and, with greater emphasis, that of Queen D. Maria Pia for day-care centres, gave great visibility to these new forms of assistance (Lopes, 2013). Table 1 provides a summary of the bodies responsible for public assistance to the needy in Portugal between 1890 and 1926. 
Table 1. Entities responsible for public assistance in Portugal (1890-1926)

\begin{tabular}{|c|c|c|}
\hline \multicolumn{3}{|c|}{ Constitucional Monarchy (1890-1910) } \\
\hline \multicolumn{3}{|c|}{ Public Assistance and Hospitalization } \\
\hline Ministry & Responsible Service & Period of validity \\
\hline Kingdom/Interior & $\begin{array}{l}\text { Directorate-General of Health and Public Beneficence (under the } \\
\text { supervision of Hospital Real de São José and Annexes) }\end{array}$ & 4.12.1899-9.2.1911 \\
\hline \multicolumn{3}{|c|}{ I Republic (1910-1926) } \\
\hline \multicolumn{3}{|c|}{ Public Assistance and Hospitalization } \\
\hline \multirow[t]{3}{*}{ Interior } & $\begin{array}{l}\text { 2nd Public Assistance Office of the Directorate General of Political and } \\
\text { Civil Administration (under the supervision of the Hospital de São José } \\
\text { and Annexes) }\end{array}$ & $9.2-25.5 .1911$ \\
\hline & $\begin{array}{l}\text { Directorate General of Assistance (under the supervision of the São } \\
\text { José and Annexes Hospitals / the Civil Hospitals of Lisbon) }\end{array}$ & 25.5.1911-13.7-1918 \\
\hline & Directorate-General for Civil Hospitals of Lisbon & 9.7.1918-30.9.1918 \\
\hline \multirow[t]{2}{*}{ Work } & Directorate-General for Assistance & 13.7.1918-10.5.1919 \\
\hline & Directorate-General for Civil Hospitals of Lisbon & $30.9 .1918-25.11 .1925$ \\
\hline
\end{tabular}

Source: Adapted from Pereira (2012, p. 22-24).

From 1910, with the establishment of the Republic, the secularization of childcare was consolidated. The field of assistance received special attention, starting with the need to safeguard children and young people who were in moral danger. There was a significant production of legislation that defined the assistance to the mothers of illegitimate children and the rights of non-profigurable (spurious) children, the action and protection programs for minors at risk, the creation of the Childhood Tutorship, the National Federation of Friends and Defenders of Children and the reorganization of Public Assistance. This was enshrined as a right in the new Constitution of 1911 (article 29). In this project of moral regeneration, primary education was a fundamental component, characterized by its free attendance and neutrality in religious matters. However, Republican programmes were not accompanied by consistent measures that could substantially alter the monarchic model of support for abandoned and invalid children and make the legislative frameworks produced feasible (Source, 2011).

The separation of the State and the Churches, expressed in the Decree of April 20, 1911, implied several changes in relation to assistance, in contrast to the legislation of 1901, which again authorized the establishment of religious congregations - provided that the imperative of promoting actions in the charitable and educational field was respected. The buildings and objects deemed not to be necessary for the cult would be intended for purposes of social interest, namely assistance, charity, education and instruction. As a result of the separation of Church and State and the subsequent secularization of society, the names of various welfare institutions became associated with figures of national history and culture, alternating with some international personalities, to the detriment of Christian-inspired names.

In May 1911, the law for the protection of children was promulgated, with the main purpose of "protecting, regenerating, making useful" the child "abandoned or unprotected", removing him from "addicted environments, which poison his soul and body" (Government Gazette, no. 137). The application of the principles conveyed in the law is guaranteed by two bodies: the Children's Tutorship, "a special collective court, essentially of equity, which is intended to defend and protect children in moral danger, abandoned or delinquent, under the motto: education and work" (Government Gazette, No. 137), and the National Federation of Friends and Defenders of Children. In addition to cooperating with the Children's Tutorship in complying with the judgments issued from it, the National Federation of Friends and Defenders of Children aimed to prevent and warn of the evils that could produce the psychological and moral degeneration of children (Government Gazette, no. 137). This law targeted not only the dangerous child, the 
delinquent, but also the child in moral danger (abandoned, poor, indigent), advocating two types of intervention, whose common denominator is the belief in the transforming power of education: a preventive intervention, for children in danger; and a re-educational intervention, for dangerous children (Henriques \& Vilhena, 2015; Anica, 2017).

In subsequent years, until the reform of the care services in 1919, the urgent need to free up space in public and private care institutions became increasingly clear, as did the more effective monitoring of family care in the case of children who had previously been interned in asylums (Pereira, 2012). The Hospices and Nursing Homes for Orphans and Disabled Children, under the management and administration of the Municipal Councils, continued to provide assistance to unprotected and morally endangered minors (Source, 2011).

From the middle of the 19th century on, there was an intense debate about the service of the exposed, questioning the morality and the defensibility of the Roda. The decree of November 21, 1867 extinguished the wheels of those exposed in Portugal. Abandonments corresponded to one for every eight births and the national expenditure on the wheel system exceeded 390 million kings ${ }^{1}, 70 \%$ of which was paid by the municipalities and $30 \%$ by Misericórdia de Lisboa, a district where those exposed reached $32 \%$ of the total (Lopes, 2013). In place of the abolished wheels, it was decreed the creation of hospices, intended to admit not only exposed children, but also children abandoned by their absent parents but with known identity and also daughters of indigents who cohabited with them (Lopes, 2013; Tomé, 2012). The Regulation for the Hospices of the Exposed, published on August 1, 1872, established that the assistance of "exposed and abandoned minors", up to the age of seven years, was the responsibility of the Municipal Councils. From the age of seven to 18 , this responsibility was attributed to the Judge of Law. This system was accompanied by control and assistance measures for needy mothers to prevent exposure or abandonment, which started to have the desired effect when they loosened budgetary constraints (Anica, 2001). The Regulation for the service of exposed and disabled or abandoned minors (1889), published by decree on January 5, 1888, would standardize in the country a model of guardianship of minors based on the principle of controlled admission. This applied in the following situations: a) "exposed": children of unknown parents who were homeless; b) "abandoned": children of known parents who disappeared without leaving their children in the care of others; and c) "disabled": children of parents who, through death, imprisonment, degradation, advanced age or illness, could not feed them or had relatives who did so. Therefore, the process of replacing, in the second half of the nineteenth century, the Roda system by the hospice system, which is at the origin of the contemporary childcare system, is slow, non-linear and not uniform in time and space (Tomé, 2012; Lopes, 2013).

\section{Horta's Disabled Childhood Asylum}

The Asylum for the Destitute Childhood of Horta (AIDH), located in the city of Horta, Ilha do Faial, in the Azores, Portugal, was founded on December 28, 1858 - the day of the Innocent Saints for the Catholic Church - with the mission of helping the helpless poverty of exposed women. The asylum was installed in a rebuilt building that had originally housed the Convent of Santo António, with its church and surrounding fence.

In the mid-19th century, Faial Island had a significant number of abandoned, unprotected, begging or exploited children. There were economic and social difficulties, culminating even in

\footnotetext{
${ }^{1}$ The Portuguese currency at the time.
} 
food crises on the islands of Faial and Pico in 1858, 1859 and 1860 (Historical memoir on the invalid childhood azylo of the city of Horta, 1884, p. 3) which justified this number of exhibitors on Faial Island in the nineteenth century and for which "those exposed were one of the greatest scourges of the last century" (Ribeiro, 1998, p. 328). It is in this context that, around 1850, the problem of children exposed or rejected in this island of Faial, with 24,755 inhabitants in 1849 (Matos \& Silva, 2008), emerges as requiring a specific social response. According to the statistics presented in the Civil Government report of 1857, in the economic year 1856-1857, the district of Horta had a total of 654 exposed. In that year, 237 children were exposed (118 boys and 119 girls) and 233 were exposed (119 boys and 114 girls). Of the 237 children exposed that year, 200 were exposed on the island of Faial (entering the Horta wheel), 16 on the island of Pico (six in Madalena, six in S. Roque and four in Lages) and 21 on the island of Flores (16 in Santa Cruz and five in Lages), with no exposure on the island of Corvo (Fonte, 2013).

Among the solutions to combat this social problem of helpless, illegitimate, orphaned or endangered minors were, above all, the house of the wheel of the exposed, the breast nurses and the breastfeeding allowance for single mothers to raise their children, some of them working simultaneously at certain times (Ribeiro, 1998). However, the district of Horta had little institutional supply to deal with this problem reality. According to the Civil Government report of 1857, there were three Mercies, one in the city of Horta and the others in the municipalities of Lajes and S. Roque, on the island of Pico. However, only the former had sufficient income to meet the needs.

On January 28, 1858, the new Civil Governor of the District of Horta, António José Vieira Santa Rita, who had founded the Asylum of Mendicidade da Horta in 1843 (Lima, 1943/1981), appointed a new Commission, with the purpose of creating a Brotherhood that would ensure both the administration of the Church and the former Convent of Santo António and the respective enclosure, and the installation of an Asylum of Disabled Childhood in this place. This Commission was successful in its aim regarding the establishment of the Asylum of Unvalid Childhood, since it started operating with six girls admitted on December 28, 1858 - the Day of the Innocent Saints for the Catholic Church, with the approval of the "princes of the island".

This asylum, aimed at "disabled" children, institutionalizes the ideological-doutrinal, charitable and philanthropic positions of its leaders in relation to the social issue of children, defending the assistance to poor children as a way to guarantee the future of "race", which was wanted morally and physically strong. Priority was given to the education of these children and the fight against infant mortality as a way of overcoming this social problem, which was essentially recognised and legitimised by doctors, hygienists and educators.

The assistance strategies developed by the dominant social groups in the Constitutional Monarchy and in the First Republic, which favoured intervention in the sphere of so-called social problems, namely that of the "invalid" childhood, focused on the ideology of custody and protection. Under this ideology, it was intended to remove children and women, especially those belonging to the popular classes, from the public space of the street and the productive activities, and it was sought to contain them in places specially delimited and prepared to welcome and monitor them (Almeida, 2000).

The IACHR, the social unit for the experience of children and youth in a common residence, thus consisted of a collective unit for the reception of unprotected children and youth (Lemos, 1958; 
Lobão, 1998; Fernandes, 2003, 2004; Serpa, 2014a, 2014b). Pillar institutions are spaces for caring for people who are considered incapable and harmless and who fit into the total institutions (Goffman, 1961: Serpa, 2013).

With the implantation of the Republic in 1910, the importance and centrality of the Law of April 20, 1911 was revealed once again. In the case of the Asylum of Disabled Childhood, there was a need to make explicit its statutory adherence to the new regime, given the few but very significant differences between this Statute of 1913 and the Statute of 1860. It seems to be a matter of a change in the statutes, motivated primarily by external questions, by a constrained conversion, since, at the level of its Statutes, the ends of the Confraternity are maintained ("the worship of St. Anthony and the support of the Assylo of invalid childhood, existing in the extinct convent of St. Anthony" [Statutes of 1913, Chapter 1.The following changes are identified as relevant: the fact that the Butler will be elected by his or her peers at the Administrative Table, no longer being designated by the Civil Governor of the District of Horta (Art. In the case of the budget of the Ministry of Finance, the law of 20 April 1911 has been explicitly referred to on several occasions; the self-imposed application of the budget to expenditure on cultural acts (Statutes of 1913, Chapter 9, Article 51 of the Statute of the Ministry of Finance) has also been included in the budget.In addition, at the level of the administration of the Confraternity, which is also very similar to the Statutes of 1860, with the very significant exception of a caveat that appears in these Statutes - the impossibility of ministers of any religion or church being elected to the Administrative Table (Chapter 3, Art. 12, 4), in another example of the separation between the State and religion, in another formal control of the religious dimension in the Statutes. However, there remain religious references: "the brothers in the religious solemnities will wear purple opa, with this on the right side the weapons of St. Anthony" (Statute of 1913, Chapter 2, Art. 8).

\section{Child care in Faial's newspapers invalid}

In the period covered by this research, the number of inhabitants of Faial Island varied between 22,000 and 26,000 inhabitants (Matos \& Silva, 2008; Lima, 2005). Azorean society was very hierarchical, ruralist, conservative and Catholic, with a low degree of industrialization, reduced relevance of urban social spaces, with a weak expression of new groups and subsequent modernizing social dynamics. Social mobility was almost zero. Despite the fact that the Azorean island society presented itself in an eminently dualistic way, that is, divided into two distinct groups (elites and people), in reality a faint and tenuous tripartite organization was being designed, with the slow growth of a limited middle class, consisting of some owners, shopkeepers or sellers, the civil service and the artisan employers (masters and workshop owners). This intermediate sector, rather heterogeneous due to its undefined contours and the multiplicity of strata, was concentrated in towns and cities and only belatedly asserted itself at the social, economic and political levels (Matos e Silva, 2008). Several of this "growing urban middle class" "in a process of affirmation", as well as with growing education, were approaching the "liberal principles of democratic features and the emerging pro-democracy ideals" (Matos \& Silva, 2008, p. 98).

Despite an enormous illiteracy in the Azores and also felt in Faial Island (Tavares, Carneiro, Diogo, \& Simões, 2009; Cordeiro, Carlos, \& Silva, 2009b.; João, 2008), a large number of newspapers appeared in Horta at that time (around a hundred), but almost all of them with a short run and duration (Lobão, 2009; Lima, 2005). Political combat journalism was very relevant in the eighteenth century and the press was militant and, in some cases, controversial. Newspapers 
were, as a rule, composed of opinion articles, the transcription of news from the continental and foreign press, information about local life, and advertisements, which constituted an increasingly valuable source of income in the dissemination of historical and cultural order. The ideological dissemination and the party struggle were one of the purposes of these journals (Lobão, 2009; Cordeiro \& Silva, 2009b; Leite, 2008).

\section{Perception of invalid childhood condition}

Childhood in social danger represented a social problem, which should be solved through a set of actions capable of modeling the individual in accordance with the values of the dominant social groups, enabling their regeneration and returning them to society. The eighteenth-century moralizing sense included actions to prevent the "evils caused by indigence": the assistance to orphans and indigent children.

Poverty and demoralisation (going against socially instituted public morality also sexually speaking as the fight against female prostitution) (Historical memory on the azylo d'infancia desvalida of the city of Horta, 1884; Ribeiro, 1998) as well as the need for greater efficiency in its control: "It is urgent to remedy the abandonment that the unfortunate people to whom the municipalities are contributing relatively large sums of money, which make it difficult for them to administer, inhibiting the chambers from extending the scope of improvements demanded by the needs of the municipalities" (cited in Ribeiro, 1998, p. 1). 334, The Fayalense, 15-5-1881).

In the discursive registers of the time, desvaler meant "to lack protection"; the adjective desvalido meant someone "unprotected, helpless" and, as a noun, it was the "poor, wretched". Thus, disablement corresponded to "lack or loss of favor, protection, validation" (Stamatto, 2017; Aulete, 1881). The difference with an abandoned person, who was also an unprotected and helpless person, was the family condition. The helpless was the smallest individual, helpless, because his family did not have the social circumstances to provide the necessary conditions for his survival because he was poor. The abandoned had no family or an adult responsible for him, so he was helpless, in poverty and without housing (Stamatto, 2017). In the relationship between the philanthropic and the Asylum: "... and those who read these lines enjoy the satisfaction of knowing that their death has been holy and religiously used in the work of mercy for which they have destined it" (O Fayalense newspaper, June 24, 1866, year 9, no 45, p. 1).

In 1892, the newspaper O Faialense reported, on the second page, the Civil Governor's speech at the feast of the Innocent Saints in 1891, in which he highlighted the humanitarian moral precept inherent to the support to be given to invalid children:

...] all the support given to disabled children is worthy of the greatest trust! Invalid childhood! In fact, this simple epigraph expresses an intuitive call to charity; it indicates a call to generous impulses of the heart and imposes a duty, not merely philanthropic, but obligatorily humanitarian, which is in the essence of social duties - to watch over man for man - and, fortunately, we see here put into practice this high moral precept (Faialense of 17 January 1892, year 35, n. 21, p. 2).

\section{Asylum assistance}

Pillar institutions were dedicated to assisting poor children while providing them with protection, education and instruction. Protection was the support and warmth of children, their cleanliness and the promotion of the progressive development of their faculties, diverting them from all dangers by means of continuous vigilance. Education would consist in strengthening children's habits of cleanliness, order, obedience, decency and respect, which are considered the mainstays 
of the life of all social classes, and in developing in their hearts, through a childhood habit, the fundamental bases of Christian virtues: love for God, continuous respect for his presence and fraternal love for other people. Instruction would be aimed at teaching students the fundamental truths of Christian doctrine, elements of sacred history, elements of reading and arithmetic, as well as a set of useful and usual notions, especially maxims and moral precepts "within reach of the first age". As for the girls, they would be additionally taught manual labor that is reputed to be suitable for their sex and age (Fernandes, 2000).

The purpose of the asylum was not limited to the protection and protection of children, but it should make possible the metamorphosis of the students into mothers of families, into helpful, honorable and honest women. Concern for women's virtue and honour prevented her from leaving institutions, except on occasions when another authority - husband, boss or superior could continue this surveillance role (Guedes, 2006). These guidelines express the centrality of domestic education in projects aimed at women's popular education (Pintassilgo, 2009), the preparation of girls for "good housewives", for mothers, for domestic arrangements, for servants, for all kinds of genuinely feminine occupations and the home (Pintassilgo, 2009; Lemos, 1924). As the newspaper O Faialense reports,

She is the first educator in that establishment of charity which goes out of there to enter into the conditions of an honorable life, which offers her the concept and esteem that an honest woman deserves in society [...] that establishment not only serves to support and protect children but also to give society helpful women and mothers of families (Faialense, 11 January 1885,28, n. 26, p. 3).

This socializing capacity of the asylum was reiterated by the newspaper O Telégrafo, which reported, on its first page, the request for marriage of a student: "That is why we see the good result of the creation of the officina attached to Asylo, where the students complete their education, making them fit to be good wives and mothers of families" ( $O$ Telégrafo, year 13, 18/07/1905, n. o 3464 , p. 1).

The moralizing function was associated with a regenerating function of soul and body:

Education is no longer the wasted children, the stunted children of the asylum. They are of good colour and nourished, and it is only for this humanitarian improvement that the administration of this institute deserves not only praise, but even assistance, because the institute's income is very small. And when we see that the teaching given in this institute to orphans beyond the primary elementary that were approved this year in the respective public exam six, and of all the more public and private schools only seven, learn to cook, wash and iron, so that the grammar, feather, pencil, needle, thimble, mop, broom and sachet silage in their hands, that there is no servant there but we must appreciate the teaching given in this institute ( $O$ Faialense of 12 January 1890, year 33, n. Article 25, p. 2).

The asylum has gained great social visibility associated with successive visits by local and regional entities, the inhabitants of Horta and neighbouring towns, to participate in various ceremonies held in its premises. The festivities of Santo António took place, generally, with the following characteristics: opening of the party to the general public; three scenes in the Church of Santo António, annexed to the Asylum; invitations to several personalities who attended the mass; mass of the party; distribution of prizes to the inmates; guests' lunch; lunch of the inmates served by personalities and attended by the general public; the inmates participated in the musical activities of the three scenes and the party (O Faialense de 30 de Maio de 1886, year 29, n. The Faialense of 20 June 1886, year 29, n. ㅇ 47, p. 3; The Faialense of 26 June 1887, year 30, n. ㅇ 48, p. 3). The importance given to the teaching of music, songs and instruments was associated with the 
monitoring of funerals, the holding of peditories by the children and the fact that these children were seen as privileged intermediaries to attend to the pleas and desires of benefactors (Guedes, 2006).

Regarding the festivity of Saint Anthony, the published opinion was praiseworthy: "during the day that building was very visited, everything being in the best order" (O Telégrafo, year 20, 17/06/1902, n. $\cong 5474$, p. 3); "under the direction of the administrative table of the Asilo de Infância Desvalida, attached to the church of Saint Anthony [...] everything went admirably, singing the mass in a very appreciable way. The whole building of the asylum was in excellent order and the students had a magnificent appearance, which honours the direction of that pious establishment" (O Telégrafo, year 13, 26/06/1904, n. 3447, p. 1). 1); "the attached Asylum, as usual, was visible to the visitors, everything being seen in the best order and cleanliness" (The Telegraph, year 15,06/26/1907, p. 3); "the asylum was much visited, good order and dinner offered by the chief of the district" (The Telegraph, year 27, 06/28/1909, no. 4610, p. 3).

The Telegraph published, on the second page, that on January 1, 1911 would be celebrated the festivity of the Innocent Saints in the Church of Santo António, with mass sung and sermon, with music assured by guests outside the Asylum, the Matrix Chapel and the Symaria Orchestra, before the procession of the Child Jesus with the Faialense Artist Philharmonic and, after the feast, a dinner served in the shelters, an offer from the Governor, the asylum being open to the public ( $O$ Telégrafo, year 19, 27/12/1910, n. Article 5053, p. 2).

\section{Assistance strategies: charity and philanthropy}

The assistance and the inherent assistance strategies developed by the dominant social groups aimed to provide help, help, and solve situations of deprivation, and were aimed at individuals or groups considered needy and deserving of assistance. Assistance could be increased through charitable and philanthropic strategies. It can be considered that the greatest difference between charity and philanthropy is not in the action itself, but in the means of carrying it out, because charity, being a pious work, presupposes the abdication of all vanity on the part of its author, advocating anonymity as the maximum value, while philanthropy, being a gesture of utility, has a central element in advertising (Sanglard, 2003).

However, for individuals who advocate the opposition between charity and philanthropy, there is a clear separation between the two. For some, charity is love for mankind through God, without ever setting it aside, attributing alms to those most in need. According to this conception, the Church rejects man's capacity and his act if he does not pay attention to God. It also rejects the benefactor's media exposure. For those who defend philanthropy as an autonomous concept, it presents itself as rational, secular, with a broader social purpose, where man and the State must intervene. Collaboration between different sectors of society should culminate in raising money for certain works. For these fundraisers, subscriptions and dances were held, among many other public events, where the mundane and the welfare purpose were mixed (Cordeiro, 2012).

Last Sunday the feast was celebrated in the Church of St. Anthony, which is dedicated to this saint and which does not allow itself to be realized on the proper day. There was a lot of competition. At the Asyladas dinner some gentlemen and many people of the people attended. Before dinner the creeds sang a hymn in praising God for saving them from misery and hunger. It's an edifying and intermingling act." (The Fayalense of 29 June 1862, year 5, no. 47, p. 4).

In May 1907, the newspaper O Telégrafo publicly praised the actions of the President and the Administrative Board of Asylum, in which it was suggested that, with the approach of the feasts of the Holy Spirit, the Brotherhoods and Reverend Parish Priests should recommend the Asylums 
of Mendicity and Invalid Childhood: "Houses of charity which have recently been imposed on public charity for their honest administration, for their good application to the disabled poor and to unhappy children" (The Telegraph, year 15, 11/05/1907, n. Article 3992, p. 2).

Charity was linked to Christian piety, which motivates people to help others. It was an attitude of particular character, which was symbolised by almsgiving. The exercise of charity was translated into alms given by the students to other poor people; the remains of the meals were distributed to the beggars, transforming the children who had been sheltered into subjects and objects of charity at the same time. The visit to the sick made it possible to make the internees and other individuals understand the value of charity in the eyes of God (Guedes, 2006).

Despite the fact that the Confraternity of Saint Anthony of Padua was an organisation which, formally, had "by means of jewels for the entry of a Brother, his annual tariffs, legacies and donations of goods from scratch, which he was allowed to acquire and alms" (Information on the Asylum, 9 September 1908, in Correspondence sent by the Confraternity of Saint Anthony of Padua and Asylo of Disabled Childhood. From 2/1/1905 to 31/12/1913), the successive budgets expressed the need to consolidate the ordinary revenues through, either the own revenues with the great importance assumed by the inscriptions of the internal debt, or the subsidy of the former General Council (of 350 thousand kings) paid by the State (The Telegraph, year 12, $12 / 08 / 1904$, n. $\cong 3193$, p. 1), with the reduction, which has already come from the previous period, of the relative importance of the eventual revenue of the alms boxes of the Church and the Market (O Telégrafo, year 18, 7/12/1910, n. ㅇ 5038, p. 2), as well as the quotas of the Brothers and the probable donations (Session of May 11, 1901, in Acts of the Confraternity of St. Anthony of Padua and Asylo of Infante Dom Luis. From 1/7/1903 to 4/9/1912). Even collective private donations - namely from the Sociedade Amor da Pátria, founded by several elements of Freemasonry, defenders of philanthropic values - had a considerable importance in the functioning of Asylum.

After the implementation of the Republic in 1910, the newspaper O Telégrafo reported that, at the level of funding sources, there were still almsgiving funds from the Church of Santo António and the Market; many donations in kind, in cash or in services provided to the Asylum continued to be received, some anonymous, sometimes with express intention or subscription, or in response to a direct request from the Asylum with public publicity (O Telégrafo, year 18, 7/12/1910, n. The Telegraph, year 19, 16/01/1911, No. 5069, p. 2; The Telegraph, year 19, 09/06/1911, No. 5181, p. 2; The Telegraph, year 19, 12/06/1911, No. 5183, p. 3).

Asylum benefactors were exalted at various ceremonies, including funeral ceremonies. In 1871, Carlos Guilherme Dabney, former American Consul of Faial, died, and his death was very much felt, "because he was loved by everyone for his affability and kindness". The funeral was attended by numerous people from all classes. The poor "lamented their orphanhood", and the children of the helpless childhood home deposited "bouquets of flowers on the grave chanting funeral verses, which caused a general commotion" (Macedo, 1887/1981, p. 371).

In the newspapers $O$ Faialense and O Telégrafo several religious ceremonies were advertised, where the benefactors of the Asylum were celebrated:

At 91.2 am on Sunday 22 nd of the current in the church of St. Anthony, the administrative table of the asylum of disabled children has a mass celebrated by suffraying the soul of counselor António José Vieira Santa Rita, founder of the hospice. All the brothers of the confraternity and those who wish to attend this act of piety are invited. The asylum will be open to anyone who deigns to visit it. (O Faialense, 22 December 1889, year 33, n. o 22, p. 4). 
The Administrative Board invites the Brothers of the Confraternity and more people to attend a Mass in the Church of Santo António for the soul of the Baron of Alagoa (António Pimentel da Silveira), who was President Butler and dedicated benefactor of the asylum, signed the Butler ( $O$ Telégrafo, year 13, 17/07/1905, n. ㅇ 3463, p. 3).

The butler-president of the Confraternity of Saint Anthony of Padua presented the Inscription of public debt, acquired by the subscription opened by a respectable and benevolent brother of the Confraternity, so that, with the interest received from this title, a prize would be awarded to the children in the hospice, who would distinguish themselves in the boarding school "for their best application, decency, activity, and cleanliness as a prize, thus commemorating the memory of the late António José Vieira Santa Rita one of the meritorious founders of the Asylum and to be distributed with the name - Prémio Santa Rita on the feast day of Saint Taumaturgo Santo António" (Session of July 16, 1898, in Book of Acts of the Asylo Infante Mr. Dom Luíz and Brotherhood of Saint António de Pádua. From 6/6/1897 to 26/8/1901).

The implementation of the Republic and the subsequent separation between the State and the Church (Catroga, 2010; Costa, 2011; Luis Martín, 2005; Pires, 2017; Sardica, 2011, 2012) did not prevent religious ceremonies and religious references from remaining highly visible. According to the Statutes of the institution, "the brothers in the religious solemnities shall wear purple opa, with this on the right side the weapons of Saint Anthony" (Statutes of 1913, Chapter 2, Art. 8). The Telegraph exalted, in its first page, the Christmas spirit present in the Santo António Asylum:

Good are those who, in the midst of the comfort of their lives, remember that the little Jesus, on the holy night of Christmas, does not descend through the cold chimney of the poor helpless children to bring them toys, and that only the angel of charity with his white wings remembers them, illuminating with a ray of joy their young hearts (The Telegraph, year 20, 30/12/1912, no. 5635, p. 1).

Imbricaded to these ceremonies and religious references were developed ceremonies where the Republican and Masonic values were exalted, namely the feast of the planting of the tree, in which were present the civil governor and the school inspector, and where were "warm live data to the Honorable President of the Republic, Doctor Manoel de Arriaga, to the Honourable President of the Council of Ministers, Doctor Afonso Costa, to the Pátria and to the Faialenses" (Extraordinary Session of March 30, 1913, in the Acts of the Confraternity of St. Anthony of Padua and Asylum of Disabled Childhood of Horta). It should be noted that the civil governor, accompanied by his wife, was regularly present at the party and Christmas dinner organized by the Asylum, where "gifts were distributed, coming from a subscription opened by the Civil Governor among his friends" (Extraordinary Session of December 26, 1912, in the Acts of the Confraternity of Saint Anthony of Padua and Asylum of Disabled Childhood of Horta).

In the commemoration of the 55th anniversary of the Asylum, this conciliation and assimilation of axiological positions of a charitable and philanthropic nature are latent in the first page of the newspaper $O$ Telégrafo, although concomitantly with the exaltation of the Republic:

At the entrance of the Civil Governor in the school room, the students sang the National Anthem, after which the Civil Governor raised a living enthusiastic to the Portuguese Republic that was warmly reciprocated by all... .

the Governor-in-Chief demonstrated the material and moral benefits resulting from the establishment of the school in this education and teaching establishment, stressing that without education and instruction the work could not be truly useful... .

Before the closing of the session, the Civil Governor, thanking all those present, asked to accompany him in a viva to the Portuguese Republic, to the President of the Republic, to the Government, to the 
administrative table, and to the Faialense People. José Garcia do Amaral and Alexandre de Lacerda were raised alive to $\mathrm{Mr}$. Governador Civil, and all were enthusiastically corresponded.

(The Telegraph, year 22, 02/01/1914, no. 5932, p. 1).

\section{Conclusion}

The discursive records produced by the press on welfare strategies value, on the one hand, an axiological dimension and forms of charitable intervention and, on the other hand, aggregate and reconcile the discourses and techniques underlying the charitable and philanthropic models. If charity has begun to assume the objectives of philanthropy, namely the "prevention of disorder", philanthropy has not completely abandoned the religious precepts. Mutual assimilation was possible because both had the same objective: the moralization and integration of invalid childhood and, above all, the protection of the existing social order.

We conclude that, perhaps contrary to what would be expected, the charitable logic articulated in a concomitant way with the philanthropic logic survived even with the stabilization of the republican period (result of a revolution that deposed the regime of the constitutional monarchy and implemented the republican regime in 1910 in Portugal whose political elites mobilized an official discourse that advocated the separation between the State and Religion, assigning the State the function of social assistance for children and youth). This denotes a certain dissociation, as well as a relative autonomy of conceptions of child and youth care between republican political ideology and current social practices, at least in this specific context.

\section{References}

Abric, J. C. (1984). A theoretical and experimental approach to the study of social representations in a situation of interaction. In: R. Farr \& S. Moscovici (eds.), Social Representations, Cambridge University Press.

Abric, J. C. (1994). L'études des répresentations sociales. In: Jodelet, D. (Dir.). Les représentations sociales. Paris: Presses Universitaires de France.

Almeida, J. F. de (1990). Portugal - Os próximos 20 anos. VIII vol. Valores e representações sociais. Lisboa: Fundação Calouste Gulbenkian.

Anica, A. (2001). A Transformação da Violência no Século XIX. O caso da Comarca de Tavira. Lisboa: Colibri.

Anica, A. (2017). Crianças em risco: uma perspetiva histórica do conceito in Anica, A. \& FreireRaposo, S. (coord.). Children at Risk. A Multifaceted View. Faro: Soroptimist Internacional Clube de Tavira/ Universidade do Algarve

Aulete, C. F. J. (1881). Diccionario Contemporâneo da Lingua Portugueza. Lisboa: Imprensa Nacional.

Bec, C., Duprat, C., Luc, J.-N., \& Petit, J.-G. (Dirs.) (1994). Philanthropies et politiques sociales en Europe (XVIIle- XXe siècles). Paris: Anthropos.

Bourdieu, P. \& Wacquant, L. (1992). An Invitation to Reflexive Sociology. Chicago: University of Chicago Press 
Bourdieu, P. (2012). Sur l'État. Cours au Collège de France 1989-1992, Paris, Seuil et Raisons d'agir,

Bremmer, R. H. (1996). Giving: Charity and philanthropy in history. New Brunswick, New York: Transaction Publishers.

Cárdenas, Y. (2010). Periodismo científico impreso en Mérida. Análisis de contenido del diário Frontera [Print Scientific Journalism in Mérida: content analisys of the newspaper Frontera]. Anuario Electrónico de Estudios en Comunicación Social "Disertaciones", 3(2), 204-231. https://revistas.urosario.edu.co/index.php/disertaciones/article/view/3930.

Carvalho, V. B., Massarani, L. M., \& Seixas, N. S. A. (2015). A cobertura de ciência em três jornais paraenses: Um estudo longitudinal [The science coverage in three newspapers of Para: A longitudinal study]. Intercom: Revista Brasileira de Ciências da Comunicação, 38(2), 207230. doi: 10.1590/1809-58442015211.

Castel, R. (2010). As metamorfoses da questão social. Petrópolis: Editora Vozes.

Castro, P. \& Gomes, I. (2005). Genetically modified organisms in the portuguese press: thematization and anchoring, Journal for the Theory of SocialBehaviour,35,1-17

Catroga, F. (2010). O republicanismo português (cultura, história e política). Revista da Faculdade de Letras - HISTÓRIA - Porto, III Série, 11, 95-119. http://ler.letras.up.pt/uploads/ficheiros/9008.pdf.

Cordeiro, C., \& Silva, S. S. (Coords) (2009a). A história da imprensa e a imprensa na história: O contributo dos Açores. Ponta Delgada: Centro de Estudos Gaspar Frutuoso da Universidade dos Açores e Centro de Estudos Interdisciplinares do Século XX da Universidade de Coimbra.

Cordeiro, C., \& Silva, S. S. (2009b). Introdução. In C. Cordeiro, \& S. S. Silva (Coords), A história da imprensa e a imprensa na história: O contributo dos Açores (pp. 9-18). Ponta Delgada: Centro de Estudos Gaspar Frutuoso da Universidade dos Açores e Centro de Estudos Interdisciplinares do Século XX da Universidade de Coimbra.

Cordeiro, R. (2012). Filantropia. As cozinhas económicas de Lisboa (1893-1911). Dissertação de Mestrado. Lisboa: ISCTE - Instituto Universitário de Lisboa.

Correia, J. C. (2001). Media e Cidadania. Algumas reflexões em torno de duas categorias modernas: consenso e ideologia, Universidade da Beira Interior, URL: http://bocc.ubi.pt/pag/correia-joao-media-cidadania.html

Costa, M. A. (2011). Euforia breve - Memórias da 1a República na Guarda. In M. A. Costa (Coord.), A Guarda no Labirinto da Primeira República (pp. 20-229). Guarda: Câmara Municipal da Guarda.

Dias, J. A. (1995). O Amor da Pátria é o único astro que nos guia - A Maçonaria na Ilha do Faial em 1892. In O Faial e a Periferia Açoriana nos séculos XV a XIX. Horta: Núcleo Cultural da Horta.

Duprat, C. (1993). Pour l'Amour de l'Humanité - Le Temps des Philantropes: la philantropie parisienne des Lumières à la monarchie de Julliet. Paris: Éditions CTHS. 
Duprat, C. (1996). Usage et Pratiques de la Philantropie: pauvreté, action sociale et lien social, à Paris, au cour du premier XIXe sciècle. Paris: Comité d"Histoire de la Sécurité Sociale.

Durkheim, E. (1993). As regras do método sociológico (5.a ed.). Lisboa: Editorial Presença.

Fernandes, R. (2000). Orientações pedagógicas das "Casas de Asilo da Infância Desvalida" (18341840). Cadernos de Pesquisa, 109, 89-114.

Ferreira, A. (1912). Alguns elementos para a historia dos serviços da Provedoria da Assistencia Publica de Lisboa. Gerencia do Provedor interino A. Aurelio da Costa Ferreira (22 de Julho de 1911 a 16 de Junho de 1912). Lisboa: Typographia José Bastos.

Fonte T. A. (2011). República, assistência e protecção social de menores em perigo moral. In Estudos Regionais, II Série, n. 4 (pp. 173-185). Viana do Castelo: Centro de Estudos Regionais.

Fonte, T. A. (2013). Comportamentos demográficos e políticas sociais em contextos geográficos diferenciados. O problema da exposição de crianças nos distritos da Horta e de Viana no século XIX. In C. Santos, \& P. Matos (Coords.), A demografia das sociedades insulares portuguesas. Séculos XV a XXI (p. 275-296). Braga: CITCEM - Centro de Investigação Transdisciplinar «Cultura, Espaço e Memória».

Freire, M., \& Leony, V. (2011). A caridade científica: Moncorvo Filho e o Instituto de Proteção e Assistência à Infância do Rio de Janeiro (1899-1930). História, Ciências, Saúde Manguinhos, 18(1), 199-225.

Gatica, O. F. (2015). La sociología de la ciencia y la reflexividad científica [Sociology of science and scientific reflexivity]. Acta Sociológica, 67, 193-220. doi: 10.1016/j.acso.2015.03.002.

Goffman, E. (1961) Asylums. New York: Doubleday/Anchor.

Guedes, A. (2006). Os colégios dos meninos órfãos (séculos XVII-XIX). Évora, Porto e Braga. Lisboa: Imprensa de Ciências Sociais.

Henriques, H., \& Vilhena, C. (2015). A Preservação da Infância: Análise de Discursos sobre a Criança em Perigo Moral (Portugal, 1910-1916). Educação em Revista, 31(2), 61-81. https://dx.doi.org/10.1590/0102-4698132627

Jedlikowska, D. (2016). In searching for science understanding. Applying the sociology of a science based approach. Journal of Education Culture and Society, 2, 11-19. doi: 10.15503/jecs.v6i2.23

João, M. I. (2008). O ensino, a cultura e as artes num processo de laicização [Teaching, culture and arts in a laicization process]. In A. T. Matos, A. F. Meneses, \& J. G. R. Leite (Eds.), História dos Açores. Do descobrimento ao século XX, Volume II [History of the Azores. From the discovery to the 20th century, Volume II] (pp. 121-146). Angra do Heroísmo: The Institute of Culture of the Azores.

Júnior, C. M., Souza, M. T. S., Parisotto, I. R. S., \& Palmisano, A. (2016). A contribuição da sociologia do conhecimento para os estudos de institucionalização e legitimação do conhecimento do campo científico [The contribution of sociology of knowledge for the studies of institutionalization and legitimation of the knowledge scientific field]. Organizações \& Sociedade, 23(77), 231-246. doi: 10.1590/1984-9230773. 
Kale-Lostuvali, E. (2016). Two sociologies of science in search of truth: Bourdieu versus Latour. Social Epistemology, 30(3), 273-296. doi: 10.1080/02691728.2015.1015062.

Keller, R. (2011). The sociology of knowledge approach to discourse (SKAD). Human Studies, 34(1), 43-65. doi: 10.1007/s10746-011-9175-z.

Lambelet, A. (2017). La philanthropie: Usages du terme et enjeux de luttes. Ethnographiques.org, 34, 1-20. Disponível em https://www.ethnographiques.org/2017/Lambelet.

Leite, J. G. R. (2008). A consciencialização de uma identidade própria. [Awareness of one's own identity]. In A. T. Matos, A. F. Meneses, \& J. G. R. Leite (Eds.), História dos Açores. Do Descobrimento ao Século XX, Volume II [History of the Azores. From the discovery to the 20th century, Volume II] (pp. 147-156). Angra do Heroísmo: The Institute of Culture of the Azores.

Lima, M. (2005). Anais do Município da Horta (História da Ilha do Faial). Horta: Edição FacSimilada da Câmara Municipal da Horta (original de 1940).

Lobão, C. (2009). "Quinto Poder" - a Imprensa Faialense entre 1857 e 1893. In C. Cordeiro, \& S. S. Silva (Coords.), A História da imprensa e a imprensa na História: O contributo dos Açores (pp. 157-181). Ponta Delgada: Centro de Estudos Gaspar Frutuoso da Universidade dos Açores e Centro de Estudos Interdisciplinares do Século XX da Universidade de Coimbra..

Lopes, M. A. (1993). Os pobres e a assistência pública. J. In Mattoso (Dir.), História de Portugal. Vol. 5 (p. 501-515). Lisboa: Círculo de Leitores.

Lopes, M. A. (2010). Proteç̧ão social em Portugal na Idade Moderna: Guia de estudo e investigação. Coimbra: Imprensa da Universidade.

Lopes, M. A. (2010b). Políticas assistenciais em Portugal no "Despotismo lluminado" e na Monarquia Liberal. Comunicação apresentada no IX Congresso da Associação de Demografia Histórica. Ponta Delgada, 16-19 de Junho.

Lopes, M. A. (2013). Os socorros públicos em Portugal, primeiras manifestações de um EstadoProvidência (séculos XVI-XIX). Revista Estudos do Século XX, 13. doi: 10.14195/16478622_13_15.

Luis Martín, F. (2005). El fracaso de la Primera República Portuguesa (1910-1926): Razones de una crisis [The failure of the First Portuguese Republic (1910-1926): Background to a crisis]. Studia Historica. Historia Contemporánea, 23, 221-248. http://revistas.usal.es/index.php/0213-2087/article/view/6032.

Macedo, A. L. S. (1887/1981). História das quatro ilhas que formam o Distrito da Horta. (II Volume) [History of the four islands that form the Horta District (Volume II)]. Angra do Heroísmo: Regional Directorate for Cultural Affairs of the Regional Secretariat for Education and Culture of the Autonomous Region of the Azores.

Macedo, I., \& Cabecinhas, R. (2012). Representações sociais, migrações e media: Reflexões em torno do papel da literacia cinematográfica na promoção da interculturalidade. In Z. PintoCoelho, \& J. Fidalgo (Eds.), Sobre comunicação e cultura: I Jornadas de Doutorandos em Ciências da Comunicação e Estudos Culturais. Braga: Universidade do Minho - Centro de Estudos de Comunicação e Sociedade. 
Massarani, L., \& Buys, B. (2007). Science in the press in nine Latin American Countries. Brazilian Journalism Research, 3(2), 77-96. doi: 10.25200/BJR.v3n2.2007.120.

Matos, P., \& Silva, S. S. (2008). Oscilações populacionais, grupos e comportamentos sociais [Population oscillations, groups and social behaviours]. In A. T. Matos, A. F. Meneses, \& J. G. R. Leite (Eds.), História dos Açores. Do descobrimento ao século XX, Volume /I [History of the Azores. From the discovery to the 20th century, Volume II] (pp. 83-120). Angra do Heroísmo: The Institute of Culture of the Azores.

Martins, E. (1998). Teoria e prática da proteç̧ão e da reeducação. Os menores deliquentes e inadaptados em Portugal (1. a República). Palma de Mallorca: Universitat de les Illes Balears.

Medeiros, F. N. S., Ramalho, M., \& Massarani, L. (2010). A ciência na primeira página: Análise das capas de três jornais brasileiros. História, Ciências, Saúde - Manguinhos, 17(2), 439-454. doi: 10.1590/S0104-59702010000200010.

Mergoupi-Savaidou, E., Papanelopoulou, F., \& Tzokas, S. (2012). Science and technology in Greek newspapers, 1900-1910. Historiographical reflections and the role of journalists for the public images of science and technology. Science \& Education, 21(3), 293-310. doi: 10.1007/s11191-010-9292-5.

Moscovici, S. (1976). La Psychanalyse, son image et son public, Paris, PUF

Moscovici, S. (1981). On social representations. In: J. P. Forgas (ed.), Social Cognition Perspectives on Everyday understanding, London, Academic Press.

Moscovici, S. (1984). The Phenomenon of Social Representations. In: R. Farr and S. Moscovici (eds.), Social Representations., Cambridge University Press.

Moscovici, S. (1988). Notes towards a description of social representations. European Journal of Social Psychology, 18, 211-250.

Paula, F. (2005). Concepções de Atendimento à Criança Pequena: Caridade, Filantropia, Assistência e Educação Infantil. Revista Línguas \& Letras, vol. 6, n.o 11. Doi: http://dx.doi.org/10.5935/rl\&l.v6i11.883

Pereira, D. (2012). As políticas sociais em Portugal (1910-1926). Tese de Doutoramento. Lisboa: Universidade Nova de Lisboa.

Pintassilgo, J. A. (2009). Educação doméstica nos asilos femininos. O exemplo do Asilo D. Pedro V de Lisboa na transição do século XIX para o século XX. Revista História \& Perspectivas, 1(38), 139-162.

Pires, A. P. (2017). As letras de uma revolução: A implantação da república em Portugal a 5 de outubro de 1910 [The letters of a revolution: The implantation of the Republic in Portugal on October 5, 1910]. Estudos Históricos (Rio de Janeiro), 30(61), 331-354. doi: 10.1590/S2178-14942017000200003.

Reis, M. F. (2016). Educação e assistência em Portugal: Ritmos e evolução. Revista Saber \& Educar [em linha], 21, 148-155. Consultado em 10 de setembro de 2017. Disponível em http://revista.esepf.pt/index.php/sabereducar/issue/view/26/showToc>. 
Sanglard, G (2003). Filantropia e assistencialismo no Brasil [Philanthropy and social services in Brazil]. História, Ciências, Saúde, 10(3), 1095 -1098.

Sanglard, G., \& Gil, C. (2014). Assistência à infância. Filantropia e combate à mortalidade infantil no Rio de Janeiro (1889-1929). Revista da ABPN, 6(14), 63-90.

Sardica, J. M. (2011). The memory of the Portuguese First Republic throughout the twentieth century. e-JPH, 9(1), 1-27.

Sardica, J. M. (2012). O poder visível: D. Carlos, a imprensa e a opinião pública no final da monarquia constitucional []. Análise Social, 203, xlvii (2), 344-368.

Silva, A. S. (2013). Processos no tempo: Uma reflexão sobre o valor que a história acrescenta à sociologia, a partir do magistério de Vitorino Magalhães Godinho []. Forum Sociológico, 23, 1-15. doi: 10.4000/sociologico.848.

Silva, A. (2017). Assistência social em Portugal na Monarquia Constitucional (1834-1910): Da doutrina política à prática no Alto Alentejo. Tese de Doutoramento Coimbra: Faculdade de Letras da Universidade de Coimbra.

Silveira, L. E. (1980). A venda dos bens nacionais (1834-43): Uma primeira abordagem. Análise Social, XVI (61-62), 87-110.

Simmel, G. (1998). Les Pauvres. Paris: PUF

Sousa, J. P. (2000). As notícias e os seus efeitos. Coimbra: Minerva.

Stamatto, M. (2017). Assistência social educativa para a infância desvalida (Brasil, 1822-1889). Revista Iberoamericana de Educación, 75, 89-110.

Tavares, C., Carneiro, A., Diogo, M. P., \& Simões, A. (2009). A imagem pública das Ciências e da Tecnologia na Imprensa Portuguesa (1900-1901). In C. Cordeiro, \& S. S. S. (Coords.), A história da imprensa e a imprensa na História: O contributo dos Açores (pp. 519-535). Ponta Delgada: Centro de Estudos Gaspar Frutuoso da Universidade dos Açores e Centro de Estudos Interdisciplinares do Século XX da Universidade de Coimbra.

Tomé, M. (2012). Justiça e Cidadania Infantil em Portugal (1820-1978) e a Tutoria de Coimbra. Tese de Doutoramento, Faculdade de Letras, Universidade de Coimbra.

Traquina, N. (1993). As notícias. in Traquina, N. (org.). Jornalismo: questões, teorias e"estórias". Lisboa: Vega.

Tuchman, G. (1993). Contando "estórias" in Traquina, N. (org.). Jornalismo: questões, teorias e"estórias". Lisboa: Vega.

Vala, J. (1993). Representações sociais - para uma psicologia social do pensamento social. In: Vala, J. \& Monteiro, M.B. (Orgs.) Psicologia Social. Lisboa: Fundação Calouste Gulbenkian.

Valence A. \& Roussiau N. (2009) L'Immigration et les Droits de l'Homme dans les Medias: Une Analyse Representationnelle en Reseau. Les Cahiers Internationaux de Psychologie Sociale, 81: 41-63. 